DIGITAL COMMONS
@ UNIVERSITY OF SOUTH FLORIDA

Volume 9

Issue 2 Fall 2019

\section{ABO: Interactive Journal for Women in the Arts, 1640-1830}

Article 6

2019

\title{
Review of Novel Ventures: Fiction and Print Culture in England, 1690-1730 by Leah Orr
}

Susannah Sanford

Texas Christian University, s.sanfordmcdaniel@tcu.edu

Follow this and additional works at: https://digitalcommons.usf.edu/abo

Part of the Dramatic Literature, Criticism and Theory Commons, Feminist, Gender, and Sexuality Studies Commons, and the Literature in English, British Isles Commons

\section{Recommended Citation}

Sanford, Susannah (2019) "Review of Novel Ventures: Fiction and Print Culture in England, 1690-1730 by Leah Orr," ABO: Interactive Journal for Women in the Arts, 1640-1830: Vol.9: Iss.2, Article 6. http://doi.org/10.5038/2157-7129.9.2.1205

Available at: https://digitalcommons.usf.edu/abo/vol9/iss2/6

This Reviews is brought to you for free and open access by Digital Commons @ University of South Florida. It has been accepted for inclusion in ABO: Interactive Journal for Women in the Arts, 1640-1830 by an authorized administrator of Digital Commons @ University of South Florida. For more information, please contact digitalcommons@usf.edu. 
Review of Novel Ventures: Fiction and Print Culture in England, $1690-1730$ by Leah Orr

\author{
Abstract \\ A review of Novel Ventures: Fiction and Print Culture in England, $1690-1730$ by Leah Orr by Susannah \\ Sanford \\ Creative Commons License \\ (c) (1) (9)
}

This work is licensed under a Creative Commons Attribution-Noncommercial 4.0 License 
Orr, Leah. Novel Ventures: Fiction and Print Culture in England, 1690-1730, University of Virginia Press, 2017. 336 pp. ISBN: 978-0-8139-4013-7.

Reviewed by Susannah Sanford

Texas Christian University

Leah Orr's book, Novel Ventures: Fiction and Print Culture in England, 1690-1730, surveys nearly five hundred fiction texts of the early eighteenth century, using digital archives to compile "facts about print culture and book history" (14-15). Her masses of data provide a narrative of the development of the novel in the early eighteenth century that eschews the usual metaphorical crutches. Orr uses digital archives and a commitment to read every fictional work of her fortyyear time period - not just the heavy hitters and chart-toppers - to move away from the restraint of "rising" novel narratives such as those of Ian Watt or Michael McKeon. Orr's data-driven examination of printed fiction argues publishers had a more significant role in the development of fiction and the novel than scholars of book history and the early novel have previously assumed.

The book is divided into two parts. In the first part, Orr tackles "Fiction in the Print Culture World," focusing on the definition of the novel, the book trade as an industry, and authorship. She argues "booksellers published what they believed would sell, and in this period they exerted far greater influence on the development of fiction than did individual authors or acts of creative genius" (5). Investigating the balance of art versus industry, Orr revisits the definition of the novel; she believes we are constrained by our twentieth-century ideas of form. To combat our "warped view" of early eighteenth-century fiction (9), Orr "read the nearly five hundred separate works of fiction printed in England between 1690 and 1730" (4) compiling data on form, authorship, length, title pages, and publishing labels. Orr displays her data in easily consumed tables, and these are a clear strength of her book. One chart in the first chapter, for example, counts the number of title pages that identify a work of fiction as a particular genre. The largest portion of texts are called "novels," followed closely by fictional works labeled "history." The difference between the two categories is only six texts. Orr moves methodically through her study of early print fiction, organizing and reorganizing data based on categories such as printer, time, genre, title, length, and paper quality.

The second and third chapters of Novel Ventures tackle the book trade and authorship, respectively. In the second chapter, "Fiction and the Book Trade," Orr demonstrates the limited scope of the consumer relative to the influence of those involved in production at any stage. According to Orr, "fewer than 20 percent of families could afford to buy fiction," and even accounting for subsequent readers of texts able to borrow or use the text without purchasing, the idea of "popular" fiction is so limited "the term does not really apply" (28). Most fiction, when available, would have been read in chapbook form, frequently containing reprints of medieval and Elizabethan texts, rather than other, newer forms of fiction. Additionally, books were priced almost exclusively according to length and materials used to create the book: "buyers were paying for the paper, ink, and labor that went into producing a printed book, not purchasing an intellectual artifact. There is no distinction in price between books of the same length but different literary merit" (35). Orr misses an opportunity here to nuance her discussion of the book selling trade. Orr decides to use "the term 'bookseller' as it was used in the eighteenth century," thereby conflating many roles within the trade (42). Though she cites Michael Treadwell's work on trade publishers, Orr chooses not to distinguish between, say, a financier 
and a book distributor. Nevertheless, Orr clearly demonstrates a need for scholarship on shorter, more cheaply printed works of the early eighteenth century, regardless of how many "booksellers" had a hand in its production. She complicates our understanding of the literary landscape of the time, opening the way for oftener read shorter works that were priced significantly cheaper and shaped the reading public by virtue of their relative ubiquity.

The third chapter, "Authors and Anonymous Publication," asks readers to reexamine authorship and the significance of anonymous fiction. Orr finds that a whopping 70 percent of fiction was published anonymously (75). Though some title pages did later reveal the initials of the author, reference another work by the same author, or mention the type of author (e.g., "by a lady"), "anonymity was significant to how contemporary readers encountered fiction" (75). Orr reorganizes her data based on decade of publication and the author information appearing on title pages or in prefaces, combining her chart with the work of James Raven, Robert J. Griffin, and John Feather on anonymity and authorship. She concludes authorship in the time would have been something of a marketing tool (99) but less of a personal "brand" in the sense of nineteenthor twentieth-century celebrity authors.

The second part, "Fiction in England, 1690-1730," focuses on the implications of the publishing industry on specifically English fiction, as the title suggests. While discussing the existence and regular publication of reprinted older works, Orr suggests in Chapter 4 that these Elizabethan and medieval works "became indistinguishable from newer tales set in the past" (115). She reaches this conclusion by looking at hundreds of title pages of works, where original publication dates are not included, nor is contextualizing material included in the prose or opening narratives. Orr believes that because original publication dates are not given, and newer fiction frequently set tales in the past, readers would not have had a clear understanding of publication history or chronological textual context. Reprinting, then, not newer works of fiction, formed the early foundations of the English canon. Here, Orr could have investigated the relationship between paratextual materials and scholarship on literacy and education in the late seventeenth and early eighteenth centuries. Because Orr included earlier arguments about the relative affluence of most readers in the time period, I wonder if readers may have had the education necessary to bring a literary historical timeline of their own to texts without the need of a date on the title page. Such a discussion using her organized data would have deepened our understanding of readership and print consumerism during Orr's time period of 1690 to 1730.

Chapter 5 focuses on translations of foreign fiction and their influence on English readership. Translations were potentially more reliable sources of income to booksellers, as they had previously done well in other markets. However, Orr argues translations, to be successful in English markets, had to "strike a delicate balance between representing the Catholic nations accurately enough to seem plausible, and making the focal point of the book something other than religion" (148). Though foreign fiction has been studied by scholars such as Ioan Williams, Michael McKeon, and William Ray, Orr begins from the premise that translations as such a significant portion of the English book market have been mostly passed over, except by a handful of scholars. Translations changed under the influence of England's politics and social climate, perhaps more than most critics have previously acknowledged.

Before the early 1700s, translations far exceeded new fiction published in England, as Orr shows in a compelling line graph as she begins the next two chapters: "Fiction with Purpose" and "Fiction for Entertainment." In the graph, the number of texts in the two categories of New 
Fiction and Translations meet in 1705, but in the following five-year increments New Fiction increases rapidly, and by 1725 there are more than forty New Fiction texts and around twenty Translations. Using her data, Orr continues by suggesting publication of new fiction increases for two reasons. First, print production was increasing in general, allowing more fiction to be included in the growth of the publishing industry (184). Secondly, a few authors broke through the market, used writing trends to their advantage, and their successful works "could sway the trend as other writers sought to imitate it" (184). The formation of genres of fictional texts, then, depended not just on innovative authors or creative genius, but also on the economics and trendy preferences of the publishing industry.

The conclusion of Novel Ventures returns to the question of the rise of the novel, suggesting the landscape of fiction in the early eighteenth century was more "diverse, experimental, and driven by what publishers thought would sell" than most critics assume (263). The world of fiction in the early eighteenth century looks very different through the lens of Orr's charts. Leah Orr's study is data-driven and methodized to include the masses of digitized texts she painstakingly examined to gain statistical information. Orr's conclusions release scholars from narratives of the "rise of the novel" that privilege fewer texts by select authors. Her counternarrative instead offers the publishing industry itself as a way to widen our view to include reprints, translations, publishing trends, page counts, and economic constraints. 